\title{
Kinetics of solute leachate from imbibing Caesalpinia echinata Lam. (Brazilwood) seeds
}

\author{
Nestor Martini Neto ${ }^{1}$,Edmir Vicente Lamarca ${ }^{2}$, Claudio José Barbedo ${ }^{3}$
}

\begin{abstract}
The electrical conductivity of leachates from imbibing seeds has been used as a vigor test for several species. The adaptation of this methodology to different species requires knowledge on the leaching kinetics of electrolytes. For Brazilwood seeds, the classic method was not satisfactory and rapid tests are essential because they have low storage capacity at room temperature. Leaching kinetics during seed imbibition is a function of physiological quality, presence or absence of seed coat, imbibing temperature and the initial moisture content of seed. In this study, the electrolyte leaching rate of six different categories of seeds, from two regions, was evaluated in seeds with and without seed coat and incubated with different moisture contents and at different temperatures. The results showed that the electrolyte leaching rate in Brazilwood seeds is independent of the physiological quality, the presence or absence of seed coat and imbibition temperature, but these factors changed the total amount of electrolytes leached. The leaching rate increased in the first few minutes of imbibition, suggesting that the adjustment of the methodology must consider the reduction in imbibition time, reduction in temperature, use of a controlled and slower pre-imbibition, and replacement of the imbibition solution after the first few minutes.
\end{abstract}

Key words: electrical conductivity, seed physiological quality, seed vigor.

\section{RESUMO}

\section{Cinética da liberação de eletrólitos pelas sementes de Caesalpinia echinata Lam. (pau-brasil) durante a embebição}

A condutividade elétrica da solução de embebição de sementes tem sido utilizada como diagnóstico do vigor de sementes de diversas espécies. Os ajustes dessa metodologia para as várias espécies requerem o conhecimento da cinética de liberação desses eletrólitos. Para sementes de pau-brasil, a metodologia clássica não se mostrou adequada e, considerando-se que elas apresentam baixa capacidade de armazenamento em temperatura ambiente, testes rápidos, como o da condutividade elétrica, são essenciais. Para tanto, deve-se conhecer a cinética da liberação de eletrólitos durante a embebição dessas sementes, em função de sua qualidade fisiológica, da presença ou ausência de tegumento, da temperatura de embebição e do teor de água inicial das sementes, que foi o objetivo deste trabalho. Para tanto, seis diferentes categorias de sementes, obtidas de duas regiões, foram analisadas quanto à liberação de eletrólitos, quando se removeu, ou não, o tegumento e, também, quando foram incubadas com diferentes teores de água e em diferentes temperaturas. Os resultados demonstraram que o padrão de liberação de eletrólitos das sementes de pau-brasil independe de sua qualidade fisiológica, da presença ou da ausência do tegumento e da temperatura de embebição, mas esses fatores alteram a quantidade total de eletrólitos liberados. Verificou-se, ainda, que há intensa liberação logo nos primeiros minutos de embebição, sugerindo que o ajuste de metodologia deve considerar a redução ao longo do período de embebição, a redução da temperatura, a utilização de pré-embebição controlada e mais lenta e a troca da solução de embebição, após os primeiros minutos.

Palavras-chave: condutividade elétrica, qualidade fisiológica de sementes, vigor de sementes.

Received:03/10/2012; Approved:17/07/2013.

${ }^{1}$ Biologist, Master of Science.Instituto de Botânica, Avenida Miguel Stéfano, 3687, 04301-902, São Paulo, Sâo Paulo, Brasil. neto_martini@hotmail.com ${ }^{2}$ Biologist, Master of Science.Instituto de Botânica, Avenida Miguel Stéfano, 3687, 04301-902, São Paulo, Sâo Paulo, Brasil. lamarcabio@ig.com.br

${ }^{3}$ Agronomist Engineer, Doctor of Science. Instituto de Botânica, Avenida Miguel Stéfano, 3687, 04301-902, São Paulo, São Paulo, Brasil. (Bolsista do CNPq.) claudio.barbedo@pesquisador.cnpq.br (corresponding author). 


\section{INTRODUCTION}

Seed samples taken from batches containing a large proportion of dead seeds or seeds that produce abnormal seedlings often show considerable leaching of solutes when imbibed in water, which is probably caused by the presence of many damaged cells (Matthews et al., 2012). Seed solutes consist mainly of amino acids, nucleic acids and lipids which have electrolytic properties that can be determined by measuring their electric charges (Krzyzanowski et al., 1991). Thus, the increase in conductivity of the imbibition solution, i.e., the reduction in the electrical resistance caused by the electrolyte leached from the seed tissues to water can be used as a diagnostic test of vigor loss and degree of deterioration (Vieira, 1994). However, the imbibition temperature and seed coat cracks may change electrolyte leaking (Carvalho et al., 2009; Ribeiro et al., 2009). Therefore, measuring the electrical conductivity of the seed imbibition solution to evaluate vigor and degree of deterioration relies on methods that avoid the influence of other variables on the results. One of the first steps to do so is to understand the leaching kinetics of these electrolytes when seeds are subjected to different procedures.

Brazilwood (Caesalpinia echinata Lam) is a species native to Brazil that has great historical and ecological importance (Rocha et al., 2007; Rocha, 2010). Because of its exploitation in the past and the lack of effective conservation policies, now Brazilwood is in the list of endangered species (Pilatti et al., 2011). Seeds of Brazilwood are tolerant to desiccation (Barbedo et al., 2002), but retain the ability to germinate for prolonged periods only when stored at $-18^{\circ} \mathrm{C}$ (Hellmann et al., 2006). The low storage tolerance at room temperature hinders the preservation of genetic material, making it essential to develop rapid diagnostic tests for deterioration of stored seeds, helping decision making on the use, disposal and replacement of seed batches. Thus, understanding the leaching kinetics during imbibition of Brazilwood seeds can provide important information for developing rapid diagnostic tests for physiological quality of seeds of this species.

From the foregoing, this study aimed at evaluating electrolyte leaching in Brazilwood seeds during imbibition in response to physiological quality, presence or absence of seed coat, imbibition temperature and initial moisture content.

\section{MATERIALS AND METHODS}

Brazilwood seeds were collected from fruits at the predehiscence stage (Borges et al., 2005) in November 2007 in the Mogi Guaçu Biological Reserve and Experimental Station, Mogi Guaçu, SP (22 $\left.15^{\prime} \mathrm{S}, 47^{\circ} 10^{\prime} \mathrm{W}\right)$ and, in
October 2008, in the Santa Carolina farm, Jaú, SP ( $22^{\circ} 19^{\prime} \mathrm{S}$, $\left.48^{\circ} 50^{\prime} \mathrm{W}\right)$. The fruits were spread out in the sun on a brick ground and covered with a 50\% shade cloth, for two days, for opening spontaneously and releasing the seeds. The seeds, considered as pre-dispersed, were stored in a cold chamber at $7{ }^{\circ} \mathrm{C}$ until the beginning of the experiments (Barbedo et al., 2002), period not exceeding three days. Part of these seeds have been subjected to artificial aging (AA) at $42{ }^{\circ} \mathrm{C}, 100 \%$ RH (Marcos Filho, 1994) for 6 and 12 $\mathrm{h}$, generating the aged pre-dispersed seeds. At the end of each AA period, the seeds were kept in a temperaturecontrolled environment $\left( \pm 20{ }^{\circ} \mathrm{C}\right)$ to reach the initial moisture content (not exceeding 20 hours) and then evaluated for germination. Seeds recently fallen to the ground (less than 24 hours) were also collected and classified as newly dispersed. This was done in the morning of the first day by removing all seeds under the tree canopy and then covering the ground with a fine screen cloth. The next day, at the same time, all the seeds that fell on the screen were collected. Part of these seeds was also subjected to the same artificial aging, generating the aged newly dispersed seeds. Thus, different types of seeds were obtained: 1) PD (pre-dispersed, hand collected); 2) PDA6 (PD aged for 6 hours); 3) PDA12 (PD aged for 12 hours); 4) ND (newly dispersed, collected after natural fall); 5) NDA6 (ND aged for 6 hours) and 6) NDA12 (ND aged for 12 hours).

Seeds of each category were evaluated for moisture content, water potential (only embryos), germination and electrolyte leaching. The moisture content was determined by the gravimetric method with oven drying, at $103{ }^{\circ} \mathrm{C}$ for 17 hours, and the results expressed as percentage on a wet basis (Brazil, 2009). The water potential was measured for embryos with a potentiometer based on the dew point temperature of the air in equilibrium with the sample examined. The potential was assessed by sorption isotherms in solutions of polyethylene glycol (PEG) of different osmotic potentials (Michel \& Kaufmann, 1973). The germination test was conducted as described by Barbedo \& Mello (2007). Germination was evaluated daily for 15 days by recording the seeds that developed the primary root (for calculating germination) and those that produced normal seedlings (for calculating the development of normal seedlings). The mean germination time was also recorded as a measure of seed vigor, according to Borghetti \& Ferreira (2004).

Electrolyte leaching was determined using a bench digital conductivity meter calibrated with standard solution $\left(146.7 \mu \mathrm{S} \mathrm{cm}^{-1}\right)$. Samples of fresh seeds were placed in $300-\mathrm{ml}$ plastic cups with $75 \mathrm{ml}$ of deionized water in a BOD incubator adjusted to constant temperature, in the dark. The result expressed in $\mu \mathrm{S} \mathrm{cm}^{-1}$ was divided by the equivalent dry weight of the sample $(\mathrm{g})$ to provide the 
leaching of solid electrolyte per unit of dry matter in $\mu \mathrm{S}$ $\mathrm{cm}^{-1} \mathrm{~g} \mathrm{~S}^{-1}$. For the equivalent in dry matter, samples were taken from each treatment for determination of total dry matter, in the same test for the determination of moisture content (Barbedo \& Cicero, 1998).

In the first experiment, in order to analyze the electrolyte leaching during the imbibition phase of seed germination, samples of the seeds PD, PDA12, ND and NDA12, collected in Mogi Guaçu, were placed in deionized water at $20^{\circ} \mathrm{C}$ for $10,30,60,90,120,180,360,720$ and 1440 minutes. After each time, electrolyte leaching was determined as described above.

In the second experiment, aiming to analyze the influence of seed coat and temperature on electrolyte leaching, ND, NDA6 and NDA12 seeds collected in Mogi Guaçu were incubated at $20^{\circ} \mathrm{C}$, with and without coat, for 180, 360, 540, 720 and 1440 minutes. PD, PDA6 and PDA12 seeds from Jaú were incubated without coat (only the embryo) at 15 and $20{ }^{\circ} \mathrm{C}$ for $720,1440,2880$ and 4320 minutes. The times of incubation were defined according to previous tests. Because the ND seeds were stored for 40 days $\left(8{ }^{\circ} \mathrm{C}\right.$ in paper bags) from the first to the second experiment, in the latter they were named $\mathrm{ND}_{s}, \mathrm{NDA}_{\mathrm{s}}$ and NDA12.

To evaluate the influence of the initial moisture content on electrolyte leaching, PD, PDA6 and PDA12 seeds from Jaú were incubated in moistened paper with pure water (2.5 times the dry paper weight) at $25^{\circ} \mathrm{C}$, for 60 and 180 minutes, based on the results of Lamarca et al. (2009). Seeds with different moisture contents had the seed coat removed and the embryos, including those not subjected to pre-imbibition, were incubated in deionized water at 20 ${ }^{\circ} \mathrm{C}$ for 180,360 and 720 minutes, to determine electrolyte leaching, as previously described.

The experiments were arranged in completely randomized design with four replications. The first experiment compared the imbibition times for each category of seed. The second experiment was arranged in a factorial design, associating coat $\mathrm{x}$ imbibition time $(2 \mathrm{x}$ $5)$, temperature $x$ imbibition time $(2 \times 5)$ and moisture content $\mathrm{x}$ imbibition time $(3 \times 3)$. Data were subjected to analysis of variance (F test) at 5\% probability level. Means were compared by Tukey test, $5 \%$ probability level (Santana \& Ranal, 2004).

\section{RESULTS AND DISCUSSION}

Analysis of variance showed significant differences for the germination, development of normal seedlings and mean germination time (Table 1), indicating that the collection method and the accelerated aging treatment were efficient to generate different categories of Brazilwood seeds, based on their physiological quality.
The electrolyte leaching increased in all seed categories until the last evaluation time (Figure 1). Only in PD seeds, from Mogi Guaçu, the leaching up to the first 10 minutes was significantly lower than that up to the 30 minutes, showing that seeds with lower physiological quality leached high amounts of electrolytes as early as the start of imbibition. However, even for seeds with higher physiological quality, the leaching values were considered high when compared with seeds of other crop or forest species, ranging from 30-160 $\mu \mathrm{S} \mathrm{cm}^{-1} \mathrm{~g}^{-1} \mathrm{~S}^{-1}$ (Marques et al., 2002; Santos \& Paula, 2005; Valadares \& Paula, 2008, Araujo et al., 2011). For Brazilwood seeds, after 10 minutes of imbibition, on average, the electrolyte leaching had reached about $20 \%$ of the total leaching within the 24 hours recommended by the test (Vieira, 1994), and after 60 minutes they had reached $37 \%$, that is, 50 minutes after the first evaluation (after 10 minutes), there was an increase of only $17 \%$ in leaching (Figure 1). The leaching of $50 \%$ of the total electrolyte occurred after 180 minutes. At the end of the imbibition (1440 minutes), the total electrolyte leached by seeds in each category followed their physiological qualities, i.e., $276,277,321$ and $340 \mu \mathrm{S} \mathrm{cm}^{-1}$ $\mathrm{gMS}^{-1}$, respectively for PD, PDA12, ND and DE12.

The application of the electrical conductivity test for seed evaluation has shown that regardless of the seed quality, the electrolyte leaching is high in the beginning, but tends to stabilize faster in higher quality seeds (McDonald, 1999; Rose et al., 2000). For Brazilwood seeds, however, we found that the general pattern of electrolyte leaching was independent of seed quality, i.e., high leaching rate within the first 10 minutes followed by subtle stabilization (up to approximately 120 minutes) and, then, again increased leaching (Figure 1). The electrolyte leaching curve followed the same trend of the water imbibition curve performed by Lamarca et al. (2009) for seeds of the same species: high water imbibition in the first 10 minutes of imbibition and stabilization near the 120 minutes (early phase II of germination). This behavior resembles the seeds of other species such as Brazilian rosewood (Dalbergia nigra (Vell.) Fr.All. Ex Benth. (Marques et al., 2002) and 'branquilho' (Sebastiania commersoniana (Bail) Smith and Downs (Santos \& Paula, 2005), differing, however, as to the time and intensity of occurrence.

Seeds of Brazilwood have characteristics that could help understand the kinetics and rate of electrolyte leaching during imbibition. One would be the short period of the early stages of germination, that is, the speed of the water entering the seed and the speed of the embryonic axis initial growth (Mello \& Barbedo, 2007), because these processes occur concurrently with the membrane system organization during imbibition (Simon \& Raja-Harun, 1972; Bewley \& Black, 1994). Another would be the rapid 
Table 1.Moisture content, water potential, germination, development of normal seedlings and mean germination time of Brazilwoodseeds with differences in initial physiological quality, collected pre and newly-dispersed in different regions and periods and subjected or not to accelerated aging. Means followed by the same letter within each experiment are not significantly different (Tukey $5 \%$ )

\begin{tabular}{lccccc}
\hline Seedcategoryandorigin & $\begin{array}{c}\text { Moisture content } \\
(\boldsymbol{\%}, \text { wetbasis })\end{array}$ & $\begin{array}{c}\text { Water potential } \\
(-\mathbf{M P a})\end{array}$ & $\begin{array}{c}\text { Germination } \\
(\boldsymbol{\%})\end{array}$ & $\begin{array}{c}\text { Normal seedlings } \\
(\boldsymbol{\%})\end{array}$ & Meantime \\
\hline PD from Mogi Guaçu & $10.81 \mathrm{~b}$ & $86.54 \mathrm{a}$ & $71 \mathrm{a}$ & $58 \mathrm{a}$ & $2.97 \mathrm{~b}$ \\
PDA12 from Mogi Guaçu & $12.43 \mathrm{a}$ & $25.61 \mathrm{c}$ & $27 \mathrm{~b}$ & $25 \mathrm{~b}$ & $3.38 \mathrm{ab}$ \\
ND from Mogi Guaçu & $10.79 \mathrm{~b}$ & $88.26 \mathrm{a}$ & $69 \mathrm{a}$ & $62 \mathrm{a}$ & $3.92 \mathrm{a}$ \\
NDA12 from Mogi Guaçu & $12.24 \mathrm{a}$ & $34.24 \mathrm{~b}$ & $20 \mathrm{~b}$ & $9 \mathrm{~b}$ & $3.91 \mathrm{a}$ \\
\hline Coefficient of variation $(\%)$ & 0.99 & 5.42 & 17.23 & 19.26 & 267 \\
\hline ND from Mogi Guaçu & $12.45 \mathrm{c}$ & $58.20 \mathrm{a}$ & $50 \mathrm{a}$ & $26 \mathrm{a}$ & $3.08 \mathrm{a}$ \\
NDA6 from Mogi Guaçu & $15.06 \mathrm{~b}$ & $36.44 \mathrm{~b}$ & $45 \mathrm{a}$ & $29 \mathrm{a}$ & $2.71 \mathrm{a}$ \\
NDA12 from Mogi Guaçu & $16.87 \mathrm{a}$ & $31.69 \mathrm{c}$ & $20 \mathrm{~b}$ & $10 \mathrm{a}$ & $3.31 \mathrm{a}$ \\
\hline Coefficient of variation $(\%)$ & 4.57 & 5.68 & 19.44 & 4.83 & 10.22 \\
\hline PD from Jaú & $10.55 \mathrm{c}$ & $75.93 \mathrm{a}$ & $90 \mathrm{a}$ & $73 \mathrm{a}$ & $2.41 \mathrm{~b}$ \\
PDA6 from Jaú & $15.03 \mathrm{~b}$ & $33.40 \mathrm{~b}$ & $65 \mathrm{~b}$ & $38 \mathrm{~b}$ & $3.73 \mathrm{a}$ \\
PDA12 from Jaú & $17.37 \mathrm{a}$ & $26.22 \mathrm{c}$ & $45 \mathrm{c}$ & $19 \mathrm{~b}$ & $3.95 \mathrm{a}$ \\
\hline Coefficient of variation $(\%)$ & 4.74 & 5.60 & 10.63 & 34.07 & 8.15 \\
\hline
\end{tabular}

A
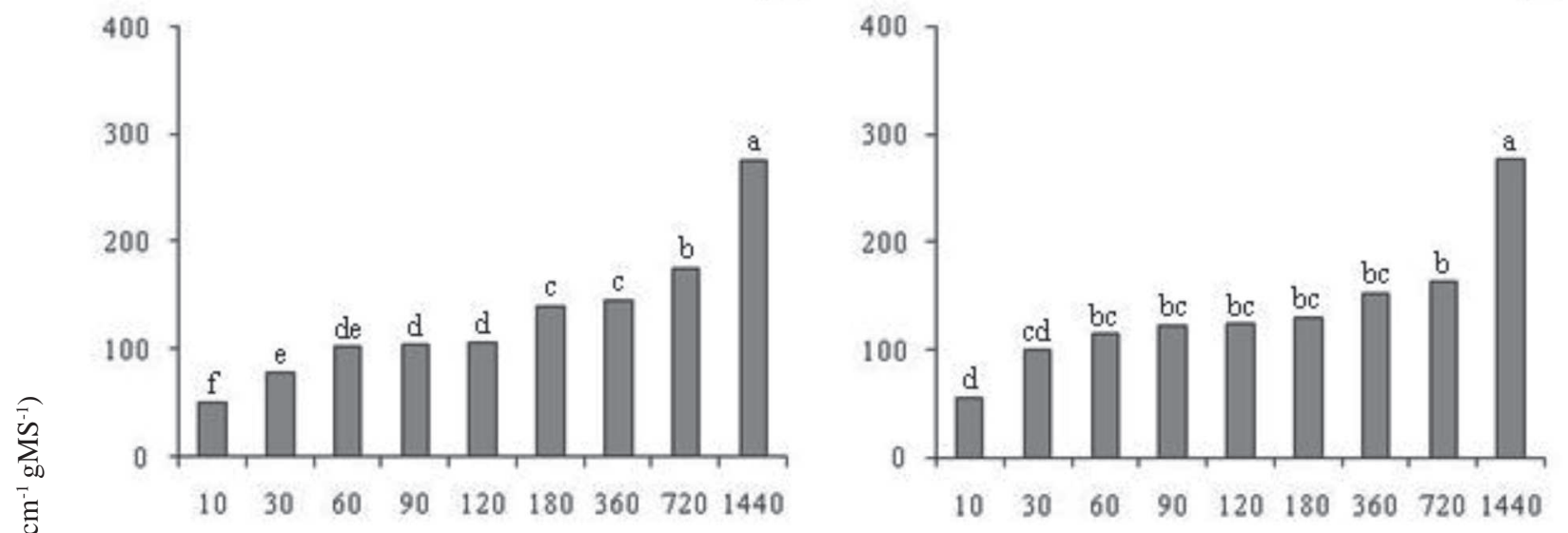

C
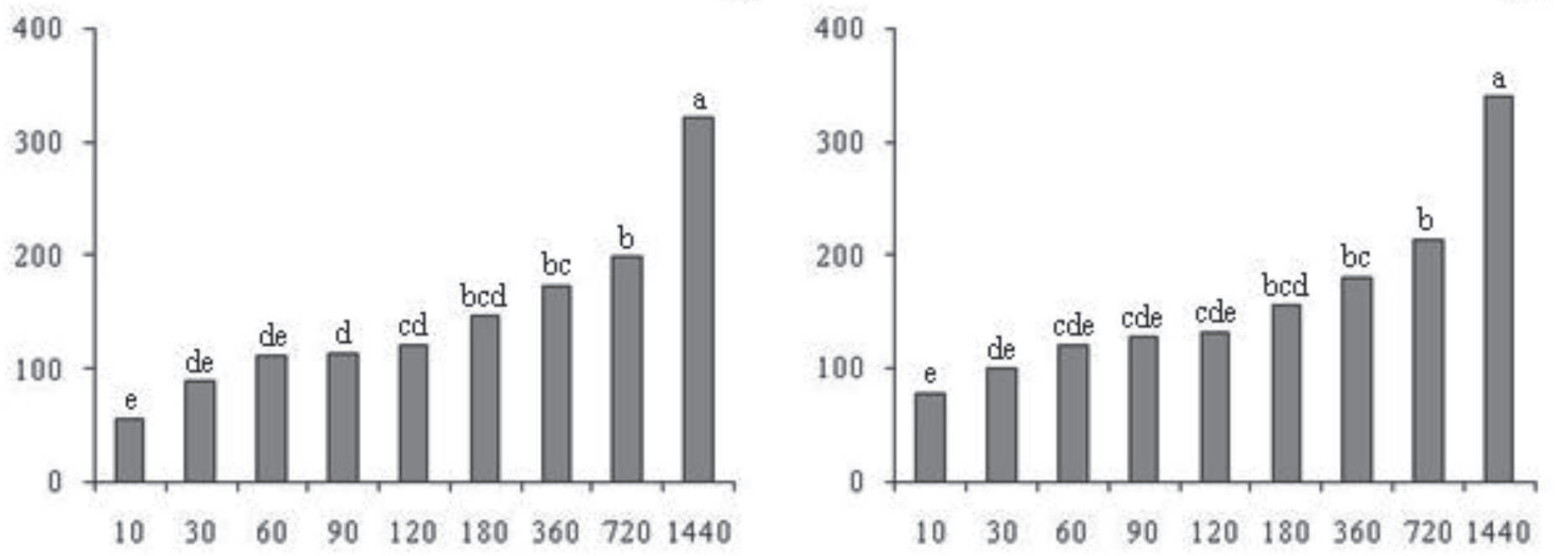

Imbibition time (minutes)

Figure 1. Electrolyte leaching by Brazilwood seeds during the imbibition. PD from Mogi Guaçu (A); PDA12 from Mogi Guaçu (B); ND from Mogi Guaçu (C); NDA12 from Mogi Guaçu (D). Columns with the same letter are not significantly different (Tukey 5\%). 
deterioration of the seed at room temperature, even with high initial quality and low moisture content (Hellmann et $a l ., 2006)$. The high electrolyte leaching could then be associated with this rapid deterioration (Møller et al., 2007).
There are other factors related to the kinetics and rate of electrolyte leaching by Brazilwood seeds, including seed coat and imbibition temperature. The analysis of variance showed no interaction between coat $\mathrm{x}$ imbibition time and

A
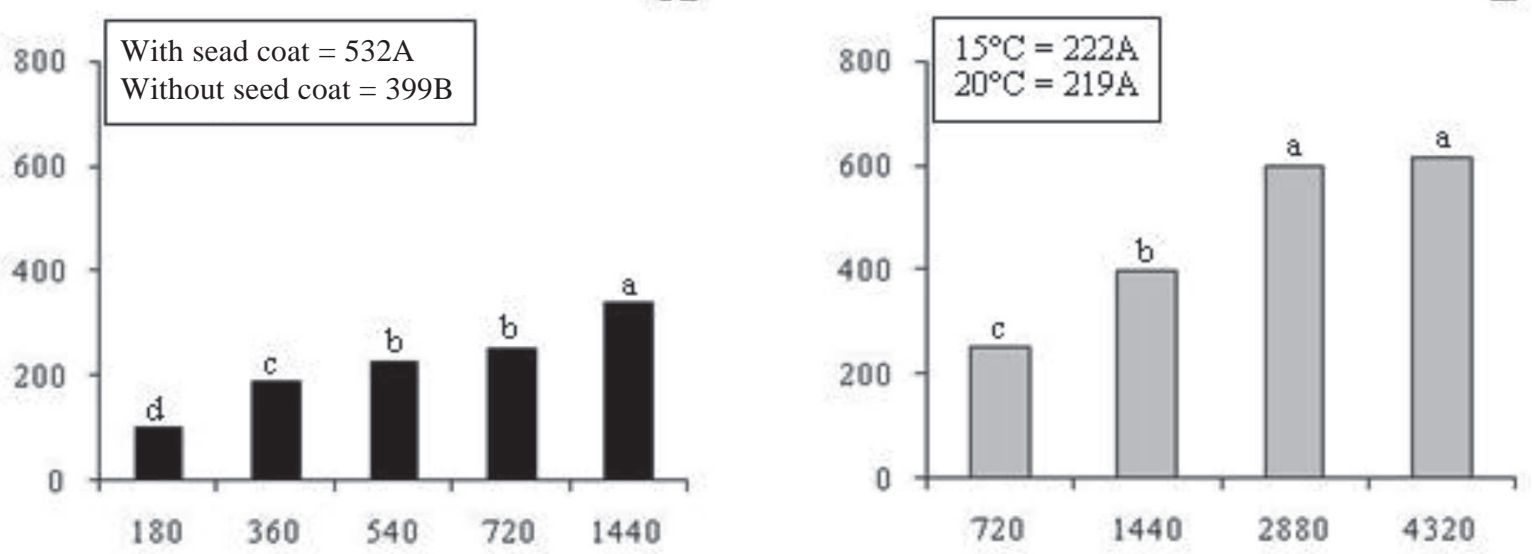

B
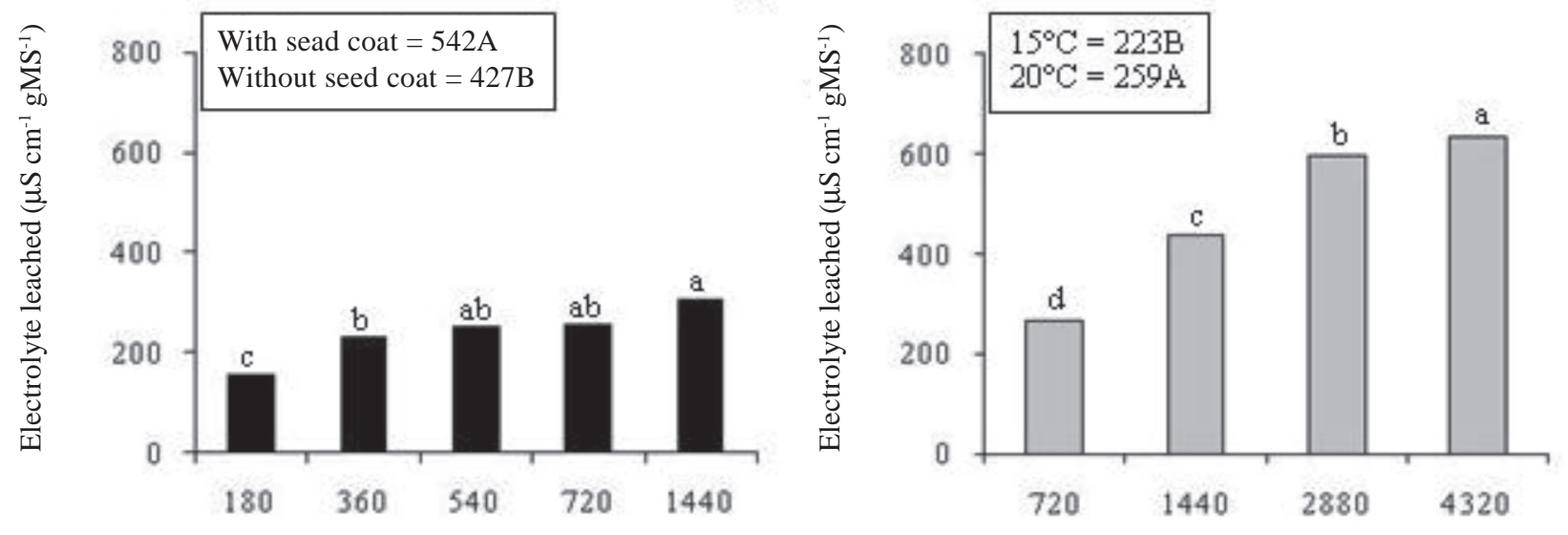

C

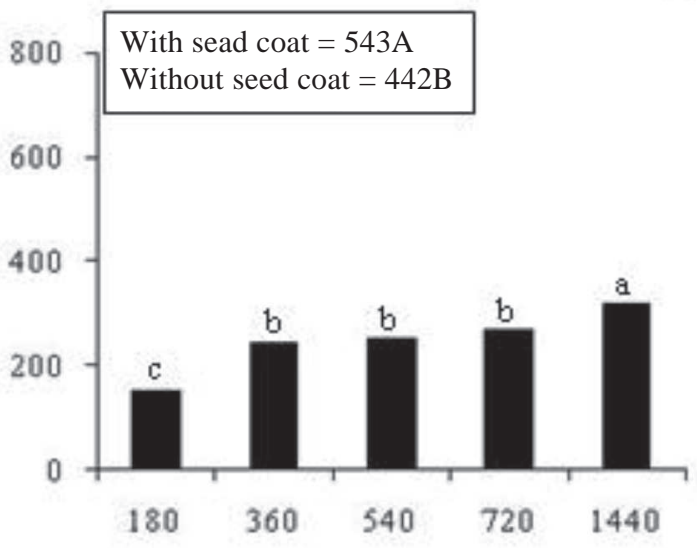

Imbibition time (minutes)

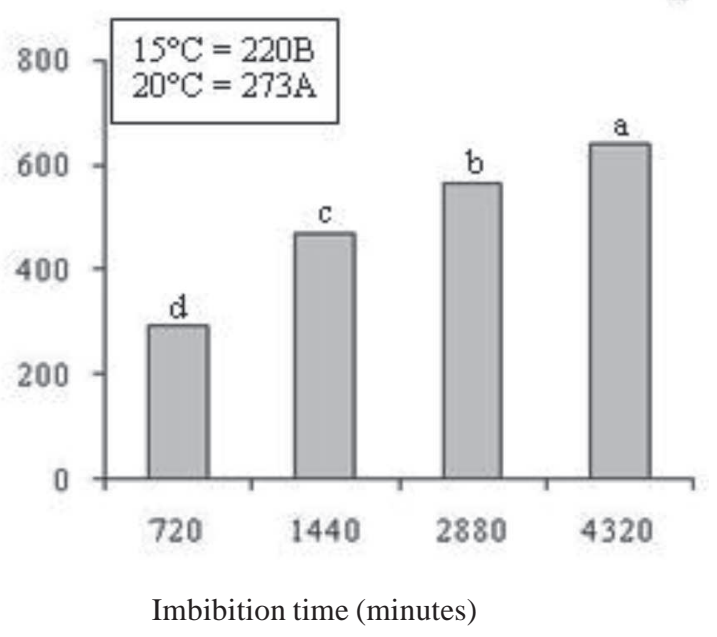

Figure 2. Electrolyte leaching by Brazilwood seeds during the imbibition. Black columns: means of seeds with and without seed coat; gray columns: means of seeds incubated at temperatures of 15 and $20^{\circ} \mathrm{C}$. Values in the boxes within each graph represent the overall mean of seeds with or without coat and seeds imbibed at different temperatures that had no interact with the factor imbibition period. $\mathrm{ND}_{\mathrm{a}}$ from Mogi Guaçu (A); NDA6 from Mogi Guaçu (B); NDA12 from Mogi Guaçu (C), PD from Jau (D); PDA6 from Jau (E); PDA12 from Jau (F). Columns with the same letter are not significantly different (Tukey 5\%). 
temperature $\mathrm{x}$ imbibition time (Figure 2) for the seeds ND, NDA6 and NDA12a, from Mogi Guaçu, and PD, PDA6 and PDA12, from Jaú (Table 1). However, the analysis showed significant differences between seeds with and without seed coat, between imbibition for 15 and $20{ }^{\circ} \mathrm{C}$ and among imbibition periods (Figure 2). The results showed that the lowest electrolyte leaching rates occurred for seeds with seed coat and lower imbibition temperature (Figure 2). The decrease in temperature increases the water viscosity, which reduces ion mobility and electrolyte leaching (Loeffler et al., 1988). For seeds of other species, such as corn and soybean, the decrease in temperature also reduced electrolyte leaching (Carvalho et al., 2009; Ribeiro et al., 2009). On the other hand, higher temperatures favor the differentiation between seed batches (Ribeiro et al., 2009). Thus, the following assays for determination of electrolytes were carried out at $20^{\circ} \mathrm{C}$.

Same as the temperature, the seed coat removal was also important for the determination of electrolytes leached. Even with higher values, the seed coat removal favored homogenization of the seeds for this analysis (Figure 2A, B and C). The seed coat of Brazilwood often has cracks and crevices and may cause undesirable variations in the determination of electrolytes leached during imbibition. Therefore, from the results of this experiment, the determination of electrolyte leaching was carried out with seeds without seed coat.

There was a continuous increase in the leaching rate with the decrease in seed quality (Figure 2 and Table 1). Above 1440 minutes, the electrolyte leaching continued to increase, but tended to stabilize, especially for PD seeds (Figure 2D), reducing the leaching rate in about four times between 2880 and 4320 minutes compared to the period between 1440 and 2880 minutes (Figures 2D - F).

The initial moisture content also influenced the electrolyte leaching during the imbibition of Brazilwood seeds. Although the correlation between most of the variables was not significant, the association between initial moisture content and electrolyte leaching after 720 minutes $(r=0.72, p<0.05)$ was significant, showing that the higher the initial moisture content of the seed batch, the greater the electrolyte leaching. However, a pre-imbibition of these seeds can change this result.

The analysis of variance of the pre-imbibition results showed interaction between moisture content and imbibition period for PD and PDA12 seeds (Figures 3A and C), but not for PDA6 (Figure 3B). The rate of electrolyte leaching by seeds without pre-imbibition (12\% water) remained high and increasing. However, after 60 and 180 minutes of pre-imbibition, seeds with 42 and $51 \%$ moisture decreased the rate of electrolyte leaching (Figure 3), regardless of seed category (PD and PDA12, Table 1). This was probably because previously imbibed seeds already had their membranes organized, avoiding the high initial leaching of electrolytes (Simon \& Raja-Harun, 1972). The initial moisture content is correlated with the rate of electrolytes leached during imbibition (Vieira et al., 2002). However, the results of this study showed that, for Brazilwood seeds, besides the initial moisture content, other factors such as the origin of the material, seed coat, imbibition temperature and initial quality influence the rate
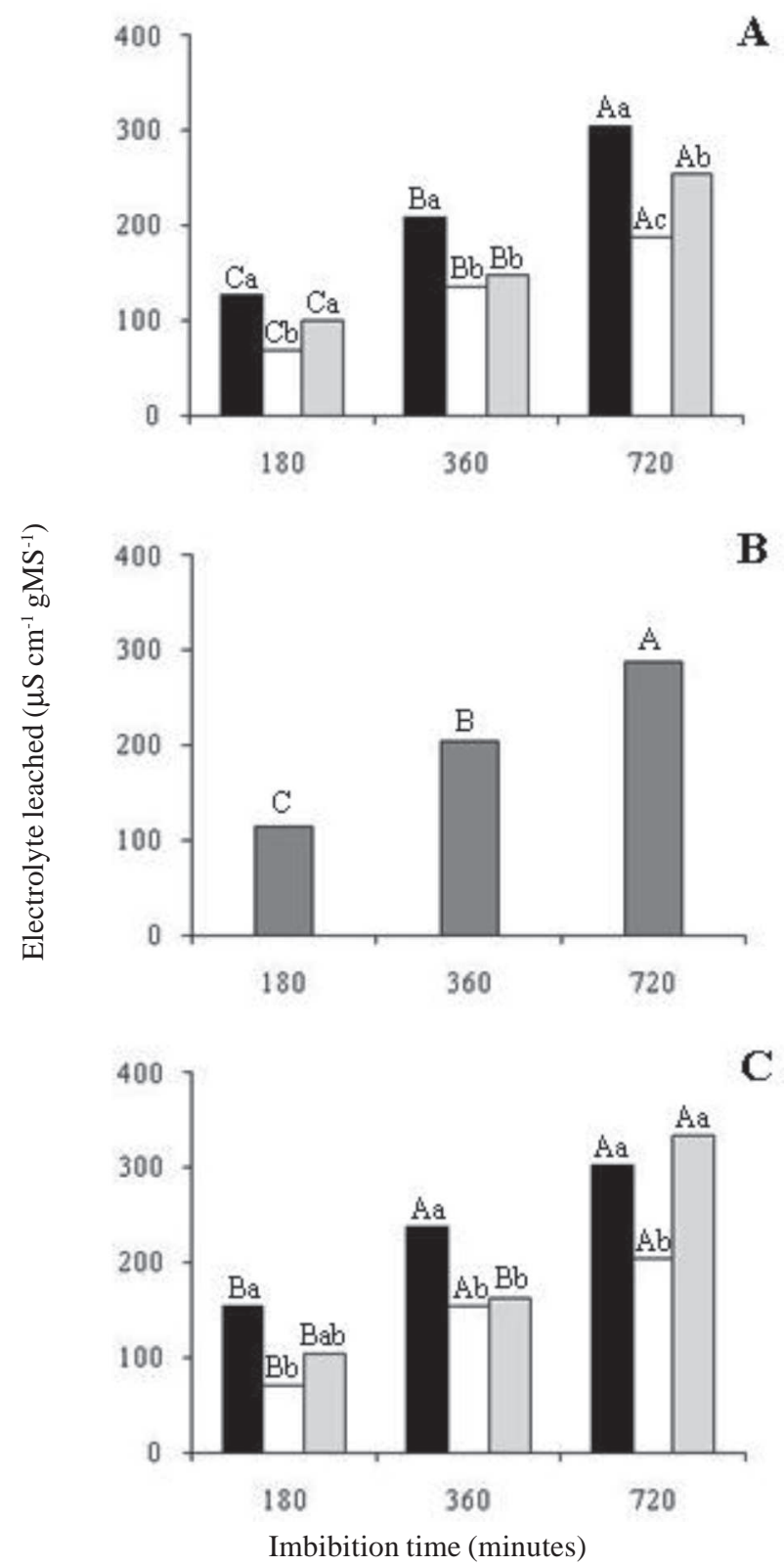

Figure 3. Electrolyte leaching by Brazilwood seeds during the imbibition. In A and C: black columns: seeds without preimbibition; white columns: seeds pre-imbibed for 60 minutes; light gray columns: seeds pre-imbibed for 180 minutes. In B: dark gray columns: means of seeds with and without preimbibition, with no significant interaction. PD from Jau (A); PDA6 from Jau (B); PDA12 from Jau (C). Means followed by the same letter (small letters compare the initial moisture content and capital letters the imbibition time) are not significantly different (Tukey 5\%). 
of electrolytes leached, but without influencing the kinetics of solute leaching. The results also showed that the adjustment of methodology for determining the degree of deterioration of Brazilwood seeds, such as the electrical conductivity test, may achieve success by reducing the imbibition period, reducing the temperature, using controlled and slower pre-imbibition and replacing the imbibition solution after the first initial minutes.

\section{CONCLUSION}

The electrolyte leaching rate of Brazilwood seeds during imbibition is independent of their physiological quality, the presence or absence of seed coat and temperature of imbibition. Nevertheless, these factors change the total amount of electrolytes leached.

\section{AKNOWLEDGEMENTS}

The authors thank Dr. Danilo da Cruz Centeno (Universidade Federal do $\mathrm{ABC}$ ) for the critical analysis of this paper. Special thanks to the staff at the Reserva Biológica e Estação Experimental of Mogi Guaçu and Santa Carolina farm for their assistance in collecting fruits and seeds of Brazilwood, the Instituto de Botânica and Santa Carolina farm for permission for seed collections; CAPES and $\mathrm{CNPq}$ for the masters scholarships granted to Edmir Vicente Lamarca and Nestor Martini Neto; CNPq for the productivity research scholarship granted to Cláudio José Barbedo (Proc. 308045/2007-6) and the financial support to the projects (Proc . 477640/2009-5 and 481484/2007-8); and FAPESP for the financial support to the project (Proc. 2005/04139-7).

\section{REFERENCES}

Araujo RF, Zonta JB, Araujo EF, Heberle E \& Zonta FMG (2011) Teste de condutividade elétrica para sementes de feijão-mungoverde. Revista Brasileira de Sementes, 33:123-130.

Barbedo CJ \& Cicero SM (1998) Utilização do teste de condutividade elétrica para previsão do potencial germinativo de sementes de ingá. Scientia Agricola, 55:249-259.

Barbedo CJ, Bilia DAC \& Figueiredo-Ribeiro RCL (2002) Tolerância à dessecação e armazenamento de sementes de Caesalpinia echinata Lam. (pau-brasil), espécie da Mata Atlântica. Revista Brasileira de Botânica, 25:431-439.

Bewley JD \& Black M (1994) Seed physiology of development and germination. $2^{\text {nd }}$ ed. London. Plenum Press. 445p.

Borges IF, Del Giudice Neto J, Bilia DAC, Figueiredo-Ribeiro RCL \& Barbedo CJ (2005) Maturation of seeds of Caesalpinia echinata Lam. (brazilwood), an endangered leguminous tree from the Brazilian Atlantic Forest. Brazilian Archives of Biology and Technology, 48:851-861.

Borghetti F \& Ferreira AG (2004) Interpretação de resultados de germinação. In: Ferreira AG \& Borghetti F (Eds.) Germinação: do básico ao aplicado. Porto Alegre, Artmed. p.209-222.

Brasil (2009) Ministério da Agricultura, Pecuária e Abastecimento. Regras para análise de sementes. Brasília, MAPA/ACS. 399p.
Carvalho LF, Sediyama CS, Reis MS, Dias DCFS \& Moreira MA (2009) Influência da temperatura de embebição da semente de soja no teste de condutividade elétrica para avaliação da qualidade fisiológica. Revista Brasileira de Sementes, 31:009-017.

Hellmann ME, Mello JIO, Figueiredo-Ribeiro RCL \& Barbedo CJ (2006) Tolerância ao congelamento de sementes de pau-brasil (Caesalpinia echinata Lam.) influenciada pelo teor de água. Revista Brasileira de Botânica, 29:91-99.

Krzyzanowski FC, França-Neto JB \& Henning AA (1991) Relato dos testes de vigor disponíveis para grandes culturas. Informativo Abrates, 1:15-50.

Lamarca EV, Leduc SNM \& Barbedo CJ (2009) Viabilidade e vigor de sementes de Caesalpinia echinata Lam. (pau-brasil Leguminosae) pelo teste de tetrazólio. Revista Brasileira de Botânica, 32:793-803.

Loeffler TM, Tekrony DM \& Egli BD (1988) The bulk conductivity test as an indicator of soybean seed quality. Journal of Seed Technology, 12:37-53.

Marcos Filho J (1994) Teste de envelhecimento acelerado. In: Vieira RD \& Carvalho NM (Eds.) Testes de vigor em sementes. Jaboticabal, Funep. p.133-149.

Marques MA, Paula RC \& Rodrigues TJD (2002) Adequação do teste de condutividade elétrica para determinar a qualidade fisiológica de sementes de jacarandá-da-bahia (Dalbergia nigra (vell.) fr.all. ex benth.). Revista Brasileira de Sementes, 24:271278.

Matthews S, Noli E, Demir I, Khajeh-Hosseini M \& Wagner MH (2012) Evaluation of seed quality: from physiology to international standardization. Seed Science Research, 22:6973.

McDonald M (1999) Seed quality assessment. Seed Science Research, $8: 265-275$.

Mello JIO \& Barbedo CJ (2007) Temperatura, luz e substrato para a germinação de sementes de pau-brasil Caesalpinia echinata Lam., Leguminosae-Caesalpiniodeae. Revista Árvore, 31:645655 .

Michel BE \& Kaufmann MR (1973) The osmotic potential of polyethylene glycol 6000. Plant Physiology, 51:914-916.

Møller IM, Jensen PE \& Hansson A (2007) Oxidative modifications to cellular components in plants. Annual Review of Plant Biology, 58:459-481.

Pilatti FK, Aguiar T, Simões T, Benson EE \& Viana AM (2011) In vitro and cryogenic preservation of plant biodiversity in Brazil. In Vitro Cellular \& Developmental Biology - Plant, 47:82-98.

Ribeiro DM, Bragança SM, Goneli ALD, Dias DCFS \& Alvarenga EM (2009) Teste de condutividade elétrica para avaliar o vigor de sementes em milho-pipoca (Zea mays L.). Revista Ceres, 56:772-776

Rocha YT (2010) Distribuição geográfica e época de florescimento do pau-brasil (Caesalpinia echinata Lam. - Leguminosae). Revista do Departamento de Geografia, 20:23-36.

Rocha YT, Presotto A \& Cavalheiro F (2007) The representation of Caesalpinia echinata (Brazilwood) in Sixteenth-andSeventeenth-Century Maps. Anais da Academia Brasileira de Ciências, 79:751-765.

Rosa SDVF, Pinho EVRV, Vieira MGGC \& Veiga RD (2000) Eficácia do teste de condutividade elétrica para uso em estudos de danos de secagem em sementes de milho. Revista Brasileira de Sementes, 22:54-63.

Santana DG \& Ranal MA (2004) Análise da germinação: um enfoque estatístico. Brasília, Universidade de Brasília. 248p. 
Santos SRG \& Paula RC (2005) Teste de condutividade elétrica para avaliação da qualidade fisiológica de sementes de Sebastiania commersoniana (Bail) Smith \& Downs - Euphorbiaceae. Revista Brasileira de Sementes, 27:136-145.

Simon EW \& Raja-Harun RM (1972) Leakage during seed imbibition. Journal of Experimental Botany, 23:1076-1085.

Valadares J \& Paula RC (2008) Qualidade fisiológica de lotes de sementes de Poecilanthe parviflora Bentham (FabaceaeFaboideae). Revista Ceres, 55:273-279.
Vieira RD (1994) Teste de condutividade elétrica. In: Vieira RD \& Carvalho NM (Eds.) Testes de vigor em sementes. Jaboticabal, Funep. p.103-125.

Vieira RD, Penariol AL, Perecin D \& Panobianco M (2002) Condutividade elétrica e teor de água inicial das sementes de soja. Pesquisa Agropecuária Brasileira, 37:1333-1338. 